\title{
Evaluation of Methane Gas to Electricity Conversion at Jatibarang Garbage Dump
}

\author{
Nurhadi $^{1}$, Enda Wista Sinuraya ${ }^{2}$ Denis $^{2}$, Jaka Windarto ${ }^{2}$, Yosua Alvin Adi Soetrisno ${ }^{2}$ \\ ${ }^{1}$ Departemen Renewable Energy, Masters of Energy, Diponegoro Universitas, Semarang, Indonesia \\ ${ }^{2}$ Departemen of electrical engineering, Diponegoro Universitas, Semarang, Indonesia \\ DOI: 10.29322/IJSRP.10.11.2020.p10750 \\ http://dx.doi.org/10.29322/IJSRP.10.11.2020.p10750
}

\begin{abstract}
Garbage was unwanted residual material after the process ends. Garbage was a problem that was often faced by cities in Indonesia, Garbage itself causes pollution around it. Jatibarang Garbage Dump, one of the Garbage Dumps located in Semarang, had a pile of garbage piling up because the amount of Garbage Dumped every day was not comparable to the storage area. One of the uses of garbage was by converting garbage into electrical energy by anaerobic. This gave an additional advantage in the utilization of landfill gas. This study evaluated the utilization of Jatibarang landfill gas in Semarang City which utilized landfill gas to generate electricity through combustion in a gas conversion generator. Semarang has a population of 1.6 million and produces around 1.270 tons of garbage per day, of which around $70 \%$ of the waste were transported and discharged to the landfill, estimating gas production of up to $600 \mathrm{~m} 3$ / hour which can be converted to $1.2 \mathrm{MW}$. The landfill gas conversion facility has become operational at the end of 2019.
\end{abstract}

Index Terms- Garbage Utilization, Waste Power Plant, Semarang

\section{INTRODUCTION}

Indonesia is estimated to produce 64 million tons of waste per year. The biggest composition of waste is $60 \%$ organic waste, followed by $14 \%$ plastic waste, $9 \%$ paper, $5.5 \%$ rubber and other waste such as metal cloth glass and the like (1). Most of the waste generated is disposed of at the final processing site (Garbage Dump) openly, even by combustion which produces highly toxic gases. Garbage is only moved and piled up in landfills. Some dumps are lowland areas outside the city, without certain technical measures as required causing health problems and environmental pollution $(9 ; 8)$.

One other concern on landfill management is the production of Greenhouse Gas (GHG) emissions due to the anaerobic decomposition process of organic waste. With waste production and composition, Indonesian waste is estimated to produce 88 MTon CO2e GHG emissions. with an average growth of $4 \%$ in the period 2000-2012, GHG emissions from waste management will grow $6.3 \%$ to reach 296 to 2030. In fact, landfill gas consists of mostly $\mathrm{CH} 4$ and $\mathrm{CO} 2$ whose production will end until all organic waste is degraded which can last for decades. Garbage Dump gas composition consists of $\mathrm{CH} 450 \%, \mathrm{CO} 240 \%$, and other gases $10 \%$ (12). With the characteristics of waste and GHG emission produced, choosing the right technology is needed in order to be able to utilize waste as an energy source (13). Adequate waste processing technology not only reduces environmental impacts but also reduces GHG emissions and saves the use of fossil energy and mitigates climate change (20).

Utilization of landfill gas as energy can replace conventional fossil energy, reducing usage and emissions associated with energy production from fossil energy. This gives an additional advantage in the utilization of landfill gas (7). Several studies have examined the use of landfill gas, for example, estimated gas production $(4 ; 11 ; 3 ; 17)$, the use of technology and its feasibility (10) as well as evaluation of landfill gas utilization (18). Some studies show potential and opportunities, but others show challenges to utilizing landfill gas. This research evaluates the utilization of Jatibarang Landfill in Semarang City of Indonesia, which utilizes landfill gas to generate electricity through combustion in a gas conversion generator. Kota Semarang, with a population of 1.6 million, produces around 1,270 tons of garbage per day, of which around $70 \%$ of the waste is transported and disposed of at the landfill (DLH Semarang, 2018). DANIDA (2015) estimates gas production of up to $600 \mathrm{~m} 3$ / hour which can be converted to 1.2 MW. The landfill gas conversion facility has become operational at the end of 2019.

\section{Research Methods}

This research is a type of exploratory research through a qualitative approach, using the case study method. The use of the case study method is driven by research questions that tend to answer the why and how. Case studies are more appropriate to explain why decisions are made, how they are done and what the results are. In addition, case studies are also very suitable for researching contemporary problems and limited levels of researcher control (21). In addition, the authors also want to present research in more detail and in a natural setting (5). The stages of research implementation include:

\section{A. Development of guiding questions}

Guiding questions are used as a reference during the interview process. This question is not binding so that it can develop according to the needs and availability of data and information. 


\section{$B$. Identification of sources}

The resource persons were identified based on expertise and linkages with facility development activities. Resource persons consisted of the Semarang City Environment Agency, ESP3 management unit, project supervisors, contractors, power plant operators, and experts from the university. There were nine speakers.

\section{Interview}

Interviews for informants who are in Semarang, interviews conducted face to face or via telephone. Speakers who are outside the region and abroad are done via email correspondence. Interviews were conducted during April 2020. This research is strengthened by a literature review of study reports and the development process as well as observations of the development process and operation of the landfill gas conversion facility

\section{Result and Analysis}

Jatibarang Garbage Dump is the only Garbage Dump currently operating in Semarang City. The landfill receives waste from 575-800 tons per day during the period 1999-2016 when a feasibility analysis of the use of landfill gas into electricity was carried out. The pre-feasibility study estimates that more than 3.5 million tonnes of waste have been buried in the Jatibarang landfill, especially in cells 1 and 2 that have been used since the landfill was operational. The composition of landfill waste consists of food waste by $43.36 \%$, garden waste by $18.58 \%$. Plastic waste is $13.4 \%$ while paper waste is $12.26 \%$. The remainder consists of textile, metal, diaper and other waste (Q2, 2015; Q2, 2016).

The Garbage Dump Jatibarang is designed with the aim to be managed in accordance with the sanitation standards of the landfill site, but during the field visit conducted in July to November 2014 the evidence of the sanitation standard was not well applied. This will cause various environmental problems to emerge which in turn will greatly affect the health and safety of the surrounding community. The area of the landfill reaches 46 hectares but the boundaries of the area are unclear while hilly and valley geographical conditions are difficult to access. The access road is very limited especially during the rainy season.

In the Jatibarang Garbage Dump there are more than 700 cattle belonging to the community at the time of the pre-feasibility study. The number was confirmed around 2,300 individuals during the data collection by DLH Semarang City in 2018. The presence of cows hindered the mobility of vehicles and heavy equipment. The presence of scavengers is also identified which impedes the compaction process by heavy equipment. The operator reported that there had been a number of fires at the Garbage Dump in the past. Most of these are small fires and fires can usually be controlled and put out. The possibility of fire is rampant in the landfill area where the trash is not covered by land and areas that are busy with scavengers. These fires are usually caused by scavengers who smoke and throw cigarette butts as well as burning cables for taking copper as recycled waste (Q2, 2015). With available waste disposal data and subsequent waste disposal until 2024, the composition of waste and the correction factor of the landfill management system, the energy potential of landfill gas is estimated to reach $600 \mathrm{~m} 3$ per hour or a maximum equivalent to 1.3 MW (Q2, 2015).

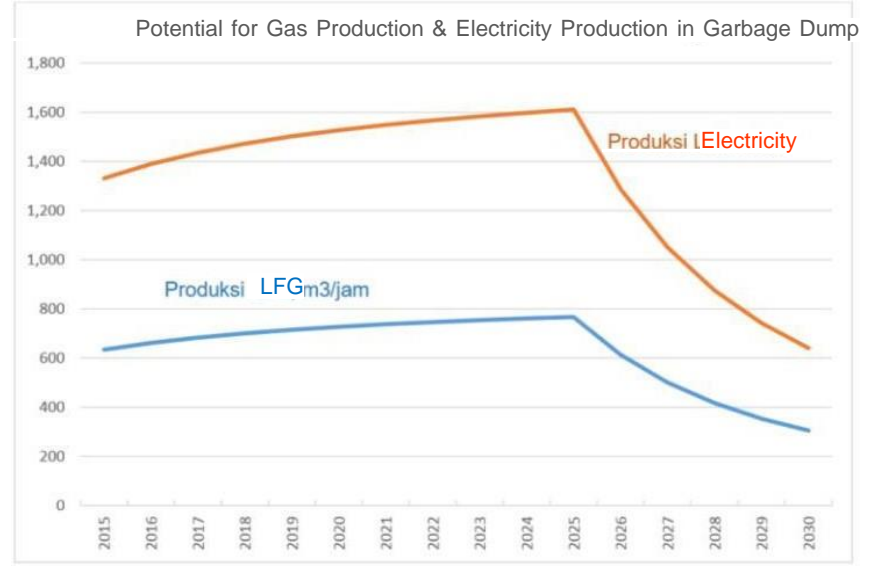

Figure. 1 Comparison of Potential for Gas Production and Electricity Production in Garbage Dump Jatibarang

The construction of a landfill gas power plant is conducted from October 2018 to December 2019. The installed gas generator capacity is $954 \mathrm{~kW}$. During the final trial process where the electricity buyer requested a $3 \mathrm{x} 24$ hour endurance test, the power plant failed to meet the requirements. The plant only managed to operate at a capacity of $800 \mathrm{~kW}$ for 4 hours. After operating for more than four hours, the landfill gas volume decreases. Likewise, methane gas concentrations decrease below $40 \%$ while gas generators require landfill gas inputs with methane gas concentrations of 50-60\%.

The power plant from Jatibarang landfill gas finally operates commercially at a capacity of $200 \mathrm{~kW}$ from an installed capacity of $954 \mathrm{~kW}$. This decrease has implications for the decline in electricity production from the original projection and in the cash flow of operators (cash flow). 
The incompatibility of landfill gas production with the pre-feasibility study (2015) and the feasibility study (2016) can be caused by various factors, which are classified into two. First, the inhibition of the extraction and transportation of landfill gas from the landfill cell to the gas well. The blocked flow of landfill gas can be caused by dirty and clogged gas wells and or the gas well is not deep enough.

The first category is completely explained as follows:

a. Gas age is inhibited by crust and dirt

There is a lag of about six months between the completion of the construction of the landfill gas conversion facility in the Jatibarang landfill and the commissioning process. This time lag causes the facility to not operate optimally. Operation of the facility is only carried out two hours every day to monitor the performance of each system. According to one of the interviewees, gas wells can be clogged with dirt which causes landfill gas from the garbage heap cannot flow, even though it is pumped with a blower. Therefore, all gas wells must be thoroughly cleaned. Although this recommendation has been made, gas production has not shown significant changes.

b. Gas depth is not deep enough

The cause of the mismatch of landfill gas production between the estimates and the actual can be caused by obstruction of the flow of gas in the cell stack to the gas well. Gas wells planted at a depth of 2.5 meters at 10 points are not enough to reach all layers of the garbage pile. The depth / height of the rubbish heap is estimated to reach 15 meters so there is a gap between the lowest rubbish and the tip in the gas well around 12.5 meters. Meanwhile, the pile of garbage has been compacted and covered with soil. With high rainfall, layers of waste within the life of the landfill can be airtight.

Cleaning and maintenance of gas wells is inadequate to reach gases arising from the lowest pile of garbage. These causes require new investment to replace gas wells with longer / deeper pipes. Although this issue was discussed during construction, the deepening of the gas well was not carried out because it followed the agreed engineering design details.

Possible causes of category two stem from the amount and type / composition of waste that is the source of landfill gas formation. According to IPCC (2006), landfill gas production is calculated based on First Order Decay (FOD), where landfill gas that arises is always proportional to the amount of degraded material. The amount of rubbish heap in one year is not associated with the amount of methane gas formed. The potential for methane generation occurs in a certain year and gradually decreases to more than a decade. The FOD model is an exponential function that explains the fraction of material that is degraded to $\mathrm{CH} 4$ and $\mathrm{CO} 2$.

The amount of landfill gas that is formed is influenced by the amount of degraded organic matter (DOCm) affected by the type of waste. The amount of landfill gas that arises is DOCm which is decomposed and influenced by the weight of stored waste (W), Degradable Organic Carbon (DOCf), decomposed DOC fraction (DOCf), and Methane Correction Factor. The MCF is determined by aerobic decomposition in the year of decomposition. This is influenced by the management of the landfill where the bush is open to oxygen, the MCF value is getting smaller so that the potential for landfill gas generation is also smaller (IPCC, 2006).

Mathematically, the potential generation of methane gas is explained in the following equation:

DDOCm $=\mathrm{W} \times$ DOC $\times$ DOCf $\times$ MCF

Where:

DDOCm the amount of degraded organic matter

W

The weight of the garbage is stored

DOC

Degraded Organic Carbon

DOCf

The Degraded Organic Carbon fraction

MCF Methane Correction Factor

DDOCm shows the total amount of landfill gas. To obtain the amount of methane gas, the $\mathrm{CH} 4$ fraction in landfill gas (F) and the molecular weight ratio of carbon in $\mathrm{CH} 4$. Mathematically explained in equation (2).

Lo $\quad=$ DDOCm $\times$ F $\times 16 / 12$

Where:

Lo Potential for $\mathrm{CH} 4$ Incidence

DDOCm The amount of degraded organic matter

$\mathrm{F} \quad \mathrm{CH} 4$ fraction in landfill gas

12/16 $\mathrm{CH} 4 / \mathrm{C}$ molecular weight ratio 
This mathematical equation explains that the potential for $\mathrm{CH} 4$ gas generation is influenced by the amount of organic waste stored and the landfill management system. PreFeasibility Study (2015) determined the MCF value of 0.4 used for the ratio of open waste management systems without compaction. This value is relatively low compared to Jatibarang landfill waste management practices that are compressed / compacted and sometimes covered with soil. The results of interviews, literature studies and observations indicate that there are allegations mismatch of landfill gas estimates for actual landfill gas generation caused by incompatible waste generation.

This can occur through three causes as follows:

A. The existence of cows reduces the amount of organic waste.

The 2,300 cows that eat organic waste, especially vegetable and fruit waste from markets and households, can significantly reduce the amount of organic material. Referring to equation (1), the amount of degraded organic matter (DDOCm) will decrease because the weight of stored waste (W) decreases, as will the Degraded Organic Carbon (DOC) and the Degradable Organic Degradable Carbon fraction (DOCf). With the amount of degraded organic matter decreasing, the potential for methane gas generation (Lo) also decreases as in equation (2).

The amount of decrease in the amount of degraded organic material does not all disappear according to the amount of organic waste eaten by cows because cows excrete feces which provide additional degraded organic material. However, additional organic material degraded from cow dung is reduced. Cow activity occurs during the day between $07.00-17.00$ WIB and then returns to the stable in and around the Jatibarang Landfill Area. Manure as long as the cow is in the drum does not add additional degraded organic material to the Garbage Dump cells that are utilized.

In addition, the characteristics of organic waste and cowfeces are different, for example the speed of degradation and decomposition that affect the accumulation of methane gas generation. Cow feces are organic waste that has obtained natural "pre- treatment" in the cow's stomach so that its speed can be different from organic waste, which according to the First Order Decay approach lasts more than a decade. Comparison of the speed of degradation of organic matter in livestock waste and organic waste needs to be further investigated to determine the effects of methane gas formation in the long run.

\section{$B$. Incompatibility of garbage disposal with closed cells}

Closed landfill cells are in zones 1 and 2 covering 9 hectares of the total landfill area reaching 46 hectares. during the operation of the landfill throughout the year, disposal is not always in the planned zone. Displacement of disposal outside the planned zone occurs due to activities to repair landfill facilities, damage to leveling and compacting equipment, limited access, especially during the rainy season and landfill assessment. Adipura's assessment activity can divert garbage disposal to cells or other zones because it requires a good image of the zone used so that a high Garbage Dump value in Adipura assessment. The landfill manager diverts some of the garbage to be disposed of in another zone so that the cows move to follow the new waste so that the assessed zone can be arranged properly.

The transfer process of waste disposal takes place in accordance with the duration of each disturbance. Disruptions occur every year so the diversion of disposal occurs every year. This reduces the weight of the garbage stored in the landfill cells that are used for electricity conversion even though it does not change the amount of waste dumped into the landfill. With the weight of stored waste (W) decreasing, the amount of Degraded Organic Material (DDOCm) decreases resulting in the potential for methane gas generation (Lo) to decrease.

\section{$C$. Incorrect recording of the weight of the garbage}

Recording weight of the garbage can be different from the garbage dumped at the landfill.This is because the weighing equipment has not been installed since the landfill was operational so that the recording in the initial operational period of the landfill is carried out by the conversion of the vehicle transport volume and the number of vehicles entering the landfill. This conversion also follows the amount of the fuel budget that is in the APBD.

\section{CONCLUSION}

1. Utilizing landfill gas into electricity is an alternative to utilizing energy as well as mitigating GHG emissions.

2. To achieve optimal benefits, estimating the amount of GHG emissions needs to pay attention to landfill management practices from operation until the closure of the landfill for the extraction and conversion of landfill gas into electricity.

3. The reduction in landfill gas can occur by landfill management practices that cause heavy waste dumped (W), Degraded Organic Carbon (DOC), Degraded Organic Carbon fraction which can be decomposed (DOCf) and Methane Correction Factor (MCF) which is not appropriate, thus affecting the Amount of Organic Material Degraded (DDOCm) and Potential Methane Gas (Lo).

4. The practice of letting cattle or other livestock in a landfill location can reduce organic waste. Although cow dung provides additional organic material, it can affect the generation of methane gas due to cattle grazing patterns (time in drums and landfills) and the different characteristics of the decomposition process.

5. The author suggests further research on the differences in the process of decomposition of organic waste and animal manure on the potential for long-term methane gas generation. 


\section{REFERENCES}

[1] BPS. (2019). Statistik Lingkungan Hidup Indonesia Tahun 2019. Jakarta: KLHK.

[2] COWI. (2018). Rencana Induk Pengelolaan Sampah Kota Semarang Tahun 2018-2038 Semarang: DLH Kota Semarang.

[3] Dewi, P. e. (2017). Potensi Energi Listrik yang Dihasilkan dari Emisi Gas Metana Di TPA Suwung Provinsi Bali.

[4] Garcilasso, V. e. (2011). Electric Energy Generation from Landfill Biogas Case Study and Barriers.

[5] Herdiansyah, H. (2010). Metodologi Penelitian Kualitatif untuk Ilmu- ilmu Sosial. Jakarta: Salemba Humanika.

[6] IPCC. (2006). 2006 IPCC Guidelines for National Greenhouse Gas Inventories-Waste Sector. IPCC.

[7] Lee, H. a. (2017). Evaluation of landfill gas emissions from municipal solid waste landfills for the life-cycle analysis of waste-to-energy pathways. Journal of Cleaner Production 106, 335-342.

[8] Lino, F., \& Ismail, K. (2013). Alternative treatments for the municipal solid waste and domestic sewage in Campinas. Resource Conservation \& Recycle $81,24-30$.

[9] Mani, S., \& Singh, S. (2016). Sustainable Municipal Solid Waste Management in India: A Policy Agenda. International Conference on Solid Waste Management (pp. 150 - 157). Procedia Environmental Sciences 35.

[10]Mbav, e. a. (2012). Feasibility and Cost Optimization Study ofLandfill Gas to Energy Projects Based on a Western Cape Landfill Site.

[11]Noor, Z. Z. (2012). An overview for energy recovery from municipal solid wastes (MSW) in Malaysia Scenario.

[12]Pawananont, K. a. (2017). Feasibility Analysis of Power Generation from Landfill Gas by Using Internal Combustion Engine, Organic Rankine Cycle, and Stirling Engine of Pilot Experiments in Thailand. International Conference on Alternative Energy in Development Countries and Emerging Economies 2017 (pp. 575-579). Bangkok, Thailand: ELSEVIER.

[13]Pecorini I, B. D. (2017). Biofiltration prototyes for methane oxidation in landifill aftercare and abatement of NMVOCs and odorous compounds. Procedia Environmental Science, Engineering and Management , 49-53.

[14]Pecorini I, B. F. (2017). Leaching behaviour of hazardous waste under the impact of different ambient conditions. Waste Management 63, $96-106$.

[15]Q2. (2015). Studi Pra-Kelayakan Pemanfaatan Gas TPA Jatibarang menjadi Listrik. Semarang: ESP3 DANIDA.

[16]Q2. (2016). Studi Kelayakan dan Preliminary Engineering Design Pemanfaatan Gas TPA Jatibarang menjadi Listrik di Kota Semarang. Semarang: ESP3.

[17]Sewchurran, S., \& Davidson, I. (2017). Study of Renewable Energy Resources Found Within Local Municipalities.

[18]Sisani, F., Contini, S., \& Di Maria, F. (14-16 September 2016). Energetic efficiency of landfill: An Italian case study. 71st Conference of the Italian Thermal Machines Engineering Association, ATI2016,. Turin, Italy: ELSEVIER.

[19]Thohiroh, \& Mardiati, R. (2014). Desain Pembangkit Listrik Tenaga Sampah (PLTSa) Menggunakan Teknologi Pembakaran Yang Fisibel Studi Kasus TPA Bantargebang.

[20]Wang, Y., He, Y., Yan, B., Ma, W., \& Han, M. (2015). Collaborative emission reduction of greenhouse gas emissions and municipal solid waste (MSW) management - case study of Tianjin. Procedia Environ. Sci. 16, 75 - 84.

[21]Yin, R. K. (2006). Studi Kasus - Design dan Metode, Terjemahan, .Jakarta: Raja Grafindo Persada

AUTHORS

First Author - Nurhadi, Renewable Energy, Masters of Energy, Universitas Diponegoro

Second Author - Enda Wista Sinuraya, Information Technology, Departemen of electrical engineering

Third Author - Denis, Energy, Departemen of electrical engineering, Universitas Diponegoro

Fourth Author - Jaka Windarto, Renewable Energy, Masters of Energy, Universitas Diponegoro

Fifth Author - Yosua Alvin Adi Soetrisno, Information Technology, Departemen of electrical engineering

Correspondence Author - Enda Wista Sinuraya, sinurayaenda@gmail.com, +62-247460057. 